\title{
SUITABILITY OF ASPEN TREES
}

AS LIVESTOCK FEED

\author{
Phase II
}

Utilization of Aspen Trees

as a

Ruminant Feed Component

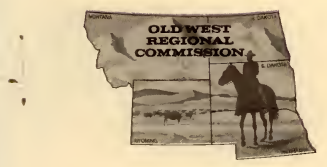

THE OLD WEST REGIONAL COMMISSION May 1977 
Montana State Library

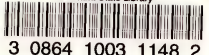

$\begin{array}{llll}30864 & 1003 & 11482\end{array}$ 


\title{
SUITABILITY OF ASPEN TREES \\ AS LIVESTOCK FEED
}

\author{
Phase II \\ Utilization of Aspen Trees
}

as a

Ruminant Feed Component

May 1977

Prepared for the Old West Regional Commission

by

The South Dakota State Division of Forestry

Department of Game, Fish and Parks

Pierre, South Dakota 57501 
The Old West Regional Commission is a Federal-State partnership designed to solve regional economic problems and stimulate orderly economic growth in the states of Montana, Nebraska, North Dakota, South Dakota and Wyoming. Established in 1972 under the Public Works and Economic Development Act of 1965, it is one of seven identical Commissions throughout the country engaged in formulating and carrying out coordinated action plans for regional economic development.

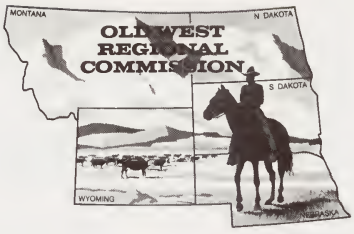

COMMISSION MEMBERS

\author{
Federal Cochairman \\ Warren Clay Wood \\ State Members
}

Gov. J. James Exon of Nebraska Alternate: W. Don Nelson

Gov. Edgar J. Herschler of Wyoming Alternate: David D. Freudenthal

Gov. Thomas L. Judge of Montana A/ternate: Keith L. Colbo

Gov. Richard F. Kneip of South Dakota

Alternate: Theodore R. Muenster

Gov. Arthur A. Link of North Dakota A/ternate: Woody Gagnon

COMMISSION OFFICES

1730 K Street, N.W. Suite 426

Washington, D.C. 20006 202/634-3907
201 Main Street

Suite D

Rapid City, South Dakota 57701

605/348-6310
228 Hedden-Empire Building Billings, Montana 59101 406/657-6665

FTS 585-6665 


\section{FOREWORD}

Building on an earlier demonstration which clearly proved the suitability of ground aspen as a component in livestock feed, this considers the economic factors of harvesting and utilizing the product for a feed component, and its competitive status in relation to traditional feeds. Like Phase I of the project, this portion of the work was conducted by the Animal Science Department of South Dakota State University at Brookings. Principal investigators were Leslie D. Kamstra, L. B. Embry and Mahendra Singh.

Warren C. Wood

Federal Cochairman 
Page No.

Conclusions

Economic Implications _._.

Raw Material Aspects

Appendix (S1aughter Data \& Taste Values)
1

Introduction -......

Study l' rocedures

Harvesting -...... 3

Processing -.

Feeding -...... 7

9

\section{TABLES}

Ration Conposition -

Chemical Composition of Rations

Composition of Aspen Chip Samples

Feedlot Performance of Six Aspen Rations - 8

Comparative Cost Data

Black Hills Aspen Resource 


\section{INTRODUCTION}

Aspen, (Populus tremıluides), which is found growing in relative abundance throughout the region, is not presently being utilized for any purpose other than for occasional use as firewood.

Due to the fact that industrial markets for aspen are virtually non-existant, the periodic harvesting of the stands necessary for their perpetuation does not occur. Consequent1y, as the individual trees age and cventually mature, they become virtually useless as a source of food and cover for wildlife, and for use in the manufacture of wood products, because of defects caused by excessive rot.

Since extensive harvesting of a timber resource cannot take place without adequate markets, it remained for someone to examine marketing possibilities for the material which could be generated in an aspen harvesting program. Most traditional markets were ruled out because the size and quality of the raw material which would be scheduled for cutting made it generally unsuitable for conversion into useful products by existing manufacturing methods. Consultations with Dr. L.D. Kamstra of the College of Agriculture and Biological Science at South Dakota State University, subsequently revealed that prior research efforts directed at utilization of wool materials for 1 ivestock feed indicated that in all likelihood, aspen trees could be converted into a suitable food for livestock. It was felt that if this could be successfully demonstrated, either a new or existing industry could capitolize on the opportunity which would result in benefits to the livestock industry, the rural economy, and the timber 
and wildlife resources. A study plan was subsequently formulated and funding approval obtained from the 01d West Regional Commission. The following section contains a orief description of the study procedure used. 
Objectives:

1. To determine whether or not aspen trees can be economically reconstituted into a form suitable for use as livestock feed at less cost per unit than traditional feeds nr-sently available.

2. To determine the value of aspen in maintenance rations.

3. To establish the value of treating aspen to increase its utilization in high roughage rations.

4. To determine the nutrient components of aspen

by analytical and other laboratory procedures.

Procedures.

\section{ᄉ. Harvesting}

A cutting site, typifying Black Hills aspen stands, was selected on National Forest lands in Township 5 North, Range 5 East, Section 17, and was sanpled for the following factors:

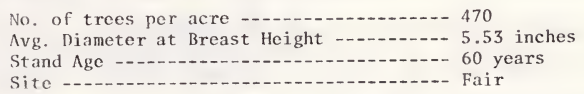

Ilar esting operitions began on June 17, 1975, after the trees had brohen dormancy and were carried on sporadically until approximately 80,000 lbs. of aspen chips had been manufactured and shipped to Egan, South lakotil for further processing. To obtain this quantity of chips required the removal of all aspen trees from an area approximately 1.3 acres in size. Using the factor of 470 trees/acre, the average tree yielded 131 lhs. of green chips. This is consistent with the results of 
an earlicr sample ohtained from Custer State Park in which the average tree was found to yield 1261 bs. of green chips.

No attempt was made to either define or utilize a "best harvesting method" for use on the project since the primary objectives dealt largely with the feeding aspects of the study. As a result, conventional logging methods were used to harvest the trees, chipping was accomplished by use of a substantially smaller chipper than those used on commercial, whole trec chipping operations, and no financial limitations were imposed on the harvesting operations other than those deemed necessary to stay within the fiscal requirements of the agreement. However, by utilizing grapple skidders and a whole tree chipper on the order of Morbarks "Chip Harvester", the combined cost of harvesting and chipping could be expected to approximate $\$ 21.00$ per green ton.

\section{B. Processing}

The green chips were trucked to Fgan, South Dakota and immediately upon arrival were put thru a dryer to reduce the moisture content, in order to retard spoilage and facilitate grinding. Following drying, they were ground to an average size of approximately 0.16 centimeter. The ground material was than mixed with additional components and pelletized to formulate the ritions listed in Table 1. 
Table 1

$\underline{\text { Ration Composition }}$

\begin{tabular}{|c|c|c|c|c|c|c|c|}
\hline$i^{2}$ & Ingredients & 1 & 2 & $\begin{array}{c}\text { Rati } \\
3\end{array}$ & $\begin{array}{r} \\
\end{array}$ & 5 & 6 \\
\hline 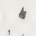 & & (Lbs. & of In & dien & 100 & . of & tion) \\
\hline i & Alfalfa & 93 & 73 & 53 & 33 & 13 & 13 \\
\hline- & Soybean 0i1 Meal* & -- & 8 & 16 & 24 & 32 & 32 \\
\hline$L$ & Aspen & -- & 12 & 24 & 36 & 48 & $48^{* *}$ \\
\hline : & Molasses & 5 & 5 & 5 & 5 & 5 & 5 \\
\hline L & Trace Minerals & 1 & 1 & 1 & 1 & 1 & 1 \\
\hline$i$ & $\begin{array}{l}\text { Dico } 1 \\
\text { Vitamin } A^{* * *}\end{array}$ & 1 & 1 & 1 & 1 & 1 & 1 \\
\hline
\end{tabular}

* Ratio of 60-40 aspen-soybean oil mix was held constant for a11 rations.

** Treated by adding $4 \% \mathrm{Na} \mathrm{OH}$ by weight.

*** 2,000 I.V. of vitamin A added $/ \mathrm{kg}$. of ration 
After formulation, the various rations were analyzed for their chemical composition. The results are contained in Table 2 .

Table 2

Chemical Composition of The Rations

$\mathbf{x}$

\begin{tabular}{|c|c|c|c|c|c|c|c|}
\hline & Ration No. & $\begin{array}{c}\text { Carotene } \\
\mathrm{Mg} / \mathrm{Ib}\end{array}$ & $\begin{array}{c}\text { Acid Detergent } \\
\text { Fiber } \\
\end{array}$ & $\begin{array}{l}\text { Crampton \& } \\
\text { Maynard Fiber } \\
\text { P E R C E T }\end{array}$ & $\begin{array}{l}\text { Crude } \\
\text { Protein }\end{array}$ & $\mathrm{Ca}$ & $\mathrm{P}$ \\
\hline & & & & & & & \\
\hline & 1 - Control & 2.20 & 42.97 & 28.90 & 12.91 & 1.62 & 0.32 \\
\hline & $2-12 \%$ Aspen & 0.98 & 37.97 & 29.36 & 13.62 & 1.35 & 0.39 \\
\hline & $3-24 \%$ Aspen & 1.32 & 38.73 & 28.62 & 15.00 & 1.38 & 0.42 \\
\hline & $4-36 \%$ Aspen & 0.72 & 35.12 & 27.91 & 16.27 & 1.03 & 0.34 \\
\hline & $5-48 \%$ Aspen & 0.62 & 34.01 & 27.82 & 16.27 & 1.08 & 0.38 \\
\hline & $6-48 \%$ Aspen \& $\mathrm{Na} \mathrm{OH}$ & 0.72 & 34.81 & 28.54 & 15.61 & 0.98 & 0.35 \\
\hline
\end{tabular}

In addition to analyzing the rations, each truck load of chips was sampled and analyzed for the following factors:

1. Moisture

2. Ash

3. Detergent Lignin

4. Detergent Fiber

5. Crampton \& Maynard Cellulose

6. Crude Protein

The resultant data is contained in Table 3 . 
Table 3

Composition of Aspen Chip Samples

\begin{tabular}{l|c|c|c|c|c|c|c}
\hline $\begin{array}{l}\text { Load No, and } \\
\text { Sample Date }\end{array}$ & Moisture & Ash & $\begin{array}{c}\text { Detergent } \\
\text { Lignin }\end{array}$ & $\begin{array}{c}\text { Detergent } \\
\text { Fiber }\end{array}$ & $\begin{array}{c}\text { Crampton \& } \\
\text { Maynard Cellulose }\end{array}$ & $\begin{array}{c}\text { Crude } \\
\text { Protein }\end{array}$ \\
\cline { 2 - 7 } $1-7 / 2$ & 11.5 & 2.19 & 8.54 & 58.84 & 46.62 & 1.38 \\
$2-7 / 22$ & 43.8 & 2.78 & 12.56 & 60.50 & 46.42 & 1.58 \\
$3-7 / 25$ & 42.7 & 4.70 & 11.46 & 54.52 & 37.82 & 1.44 \\
$4-8 / 5$ & 35.8 & 1.85 & 13.58 & 58.20 & 40.26 & 1.41 \\
$5-8 / 8$ & 38.6 & 1.77 & 14.62 & 59.50 & 42.89 & 0.90 \\
$6-8 / 13$ & 41.3 & 1.45 & 11.40 & 61.52 & 43.33 & 0.72 \\
$7-8 /-$ & --- & 1.92 & 11.98 & 58.23 & 40.88 & 0.96 \\
$8-8 / 26$ & 43.3 & 1.84 & 11.96 & 59.49 & 41.24 & 0.86 \\
\hline
\end{tabular}

C. Feeding Trials

Sixty Hereford steers weighing approximately 725 pounds each were selected and randomly sorted into 12 lots of five animals each. Feeding commenced on Ju1y 15 th and continued for a period of 93 days. The animals were cleaned and weighed on the 32 nd and 57 th days of the trial with the final weigh-in occuring on the $93 \mathrm{rd}$ day. Feeding was discontinued for several days in order to obtain the shrunk weight. Data obtained in the feeding trials is contained in Table 4, Feedlot Performance of Six Aspen Rations. 
Feedlot Performance of Six Aspen Rations

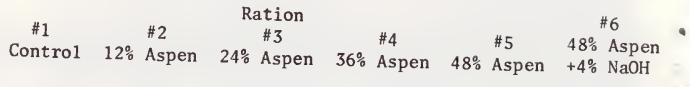

$-$

Number of Animals

Number of Days Fed

Avg. Initial Filled Wt.

Avg. Initial Shrunk Wt.

Avg. Final Filled Wt.

Avg. Final Shrunk Wt.

Avg. Daily Ration

- Consumption (1bs)
At 32 Days
At 57 Days
At 93 Days

Avg. Daily Gain (1bs)

At 32 Days
At 57 Days
At 93 Days (Filled)
At 93 Days (Shrunk)

0.94

1.69

1.55

1. 26

16.49
21.38
24.68

19.03
24.46
27.74

23.75
28.56
30.33

24.42

29.40

30.86

10

93

726

702

989

951

937

1.48
2.90
2.23
2.02

3.16

3.52

2.77

2.53
3.56

3.32

2.83

2.68
10

93
725

704

978

930
10

93

726

704

970

931
23. 25

26.14

27.81

23.71

27.42

29.09

Lbs. of Feed Consumed

Per Lb. of Gain

At 32 Days

At 57 Days

At 93 Days (Filled)

At 93 Days (Shrunk)

$$
20.31
$$

15.63

15.93

19.50
13.54

10.26

12.49

13.80

7.53
8.08
10.95
12.07

6.88

9.04

10.95

11.66
3.27

3.17

2. 72

2.42
3.63

3.16

2.62

2.44 


\section{CONCLUSIONS}

\section{A. Economic Implications}

Probably the most logical approach to an examination of the economics of feeding experimental rations is one which compares the cost per pound of gain made by the ration fed livestock with the cost per pound of gain made by the animals utilizing a conventional feed. Table 5, Comparative Cost Data, serves to accomplish this by splitting out the various cost components for viewing and than recombining them into a total cost per ration from which a figure representing cost per pound of gain can be developed for each ration fed. The cost components used include harvesting and chipping, drying, grinding, pelletizing, and bagging. The cost of transporting the aspen chips from the woods to a processing point was not included because it was felt that the extreme variations involved in trucking distances and charges, prohibits developing a truly meaningful average transportation cost figure. With the exception of the harvesting and chipping costs, all other costs used in the analysis are "as experienced" costs and should not be construed to represent the actual costs which would be experienced by a prudent entrepreneur engaged in producing a large volume of feed. Especially might this hold true for the drying and grinding costs which could be expected to be significantly less for a large scale operation.

The harvesting and chipping costs used in the analysis was selected after a search of the literature dealing with whole tree harvesting and chipping. USDA Forest Service Research Paper RM-125 titled "Demonstration 
Test of Inwoods Pulp Chip Production in The Four Corners Region" served as the major reference for this purpose, and the cost figure selected for use was purposely inflated in order to retain a somewhat "conservative" approach to the analysis.

Table 5

Comparative Cost Data

\begin{tabular}{|c|c|c|c|c|c|c|c|}
\hline Cost Item & Cost/Ton & Cost/1b & & Cost Per & Ton In & ol1ars & \\
\hline & in Dollars & in Cents & Control & $12 \%$ leve 1 & $24 \%$ & $36 \%$ & $48 \%$ \\
\hline $\begin{array}{l}\text { Harvesting \&े } \\
\text { Chipping }\end{array}$ & 20.50 & 0.01 & 0 & 2.40 & 4.80 & 7.20 & 9.60 \\
\hline Drying & 18.60 & 0.009 & 0 & 2.16 & 4.32 & 6.48 & 8.64 \\
\hline Grinding & 1.90 & 0.009 & 0 & 0.22 & 0.44 & 0.66 & 0.88 \\
\hline $\begin{array}{l}\text { Sub Total = } \\
\text { (Cost of aspen } \\
\text { portion of the } \\
\text { ration) }\end{array}$ & 41.00 & 0.0205 & 0 & 4.78 & 9.56 & 14.34 & 19.12 \\
\hline $\begin{array}{l}\text { (2) Pelletizing \& } \\
\text { Bagging }\end{array}$ & 18.00 & 0.009 & 18.00 & 18.00 & 18.00 & 18.00 & 18.00 \\
\hline $\begin{array}{l}\text { (3) Cost of the Additive } \\
\text { Portion of Ration }\end{array}$ & & & 97.75 & 96.75 & 89.00 & 81.70 & 75.20 \\
\hline $\begin{array}{l}\text { Total Ration Cost } \\
\text { (Sum of Items 1-3) }\end{array}$ & & & 115.75 & 119.53 & 116.56 & 114.04 & $112.32^{\circ}$ \\
\hline Ration Cost/Lb. & & & .058 & .060 & .058 & .057 & .056 \\
\hline $\begin{array}{l}\text { Ration Cost/Lb of } \\
\text { Gain (Shrunk wt) }\end{array}$ & & & 1.13 & .83 & .70 & .66 & .65 \\
\hline
\end{tabular}


It would appear that all aspen containing rations were significantly superior to the alfalfa control ration in average daily gain, feed requirements per pound of gain, and cost per pound of gain. The addition of Sodium Hydroxide to the rations did not increase animal utilization.

It seems likely that aspen could serve as a major component of maintenance, high roughage rations if its known nutritional deficiencies such as protein and Vitamin $A$ are corrected. It would also appear that aspen has potential value as a component of growing rations.

\section{B. Raw Material Aspects}

Aspen grows in abundance in most of the forested states west of the Mississippi, although normally the acreage occupied by the species is quite sma11 in relation to the total forested area.

It (aspen) is classified in most forest inventories as a "noncommercial" species, ie; a species having little or no potential as raw material for conversion into useful products, and as such it tends to be disregarded by most forest managers. This is especially true in the area making up the "old west region" where the aspen stands are generally small sized and are widely interspersed among extensive stands of the various coniferous species native to the area.

Forest inventory data for the Black Hills area of South Dakota, where aspen is typically found growing under the conditions described, can well serve to illustrate the potential of the resource. Although no attempt was made to determine the total quantity of aspen present in the five state area, it is estimated that the volumes set forth in Table 6, Black Hills 
Aspen Resource, represents less than one seventh of the total available for use as livestock feed.

Table 6

B1ack Hills Aspen Resource

\begin{tabular}{|l|c|c|c|}
\hline Ownership & $\begin{array}{r}1 / \text { Dry Tons } \\
(-15 \% \text { M.C. })\end{array}$ & $2 /$ Cubic Feet & \\
\hline U.S. Forest Service & 181,426 & $10,734,400$ \\
Private Lands & 48,519 & $2,870,718$ & 417,091 \\
\hline State Lands & 7,049 & $14,022,209$ & \\
\hline
\end{tabular}

1/ Includes the main stem, branches, and leaves of trees 5 inches in diameter or larger at breast height.

2/ Includes the mainstem portion only of trees 5 inches in diameter or larger at breast height.

Based on these and other data, it is estimated that a sustained yield aspen harvesting program in the Black Hills could generate from 15,000 to 20,000 tons of dry chips per year. 
$\underline{A} \underline{\mathrm{P}} \underline{\mathrm{P}} \underline{\mathrm{E}} \underline{\mathrm{N}} \underline{\mathrm{D}} \underline{\mathrm{I}} \underline{\mathrm{X}}$

\section{Slaughter Data}

(Each figure represents an average of four randomly selected animals)

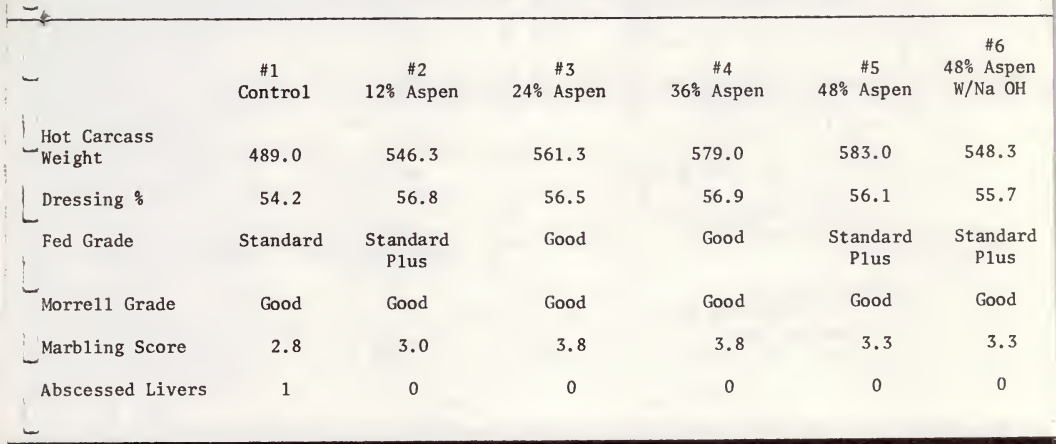

1

1

Taste Values

(10 Member Pane1)

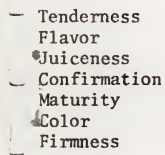

3.82
3.43
3.90
17.8
23.0
3.5
5.0

3.48

3.23

3.13

3.53

19.3

23.0

5.3

3.8

4.8

4.02

3.03

2.80

3.43

3.18

3.98

3.58

19.5

19.0

23.0

5.0

5.8

23.0

3.8

5.3

3.00

3.10

19.3

23.0

4.8

5.5

5.3 


\section{O.W.R.C ASPEN FEEDING STUDY Grant \# 10570108 \\ Statement of Expenditures}

\section{ITEM}

1. Contractual Services by SDSU College of Agriculture and Biological Sciences

2. Contract skidding expense

3. Contract labor for cutting

4. Contract chipping expense

5. Wood chip drying costs

6. Wood chip grinding costs

7. Supplies and Materials Gas and $0 i 1$

8. Miscellaneous

A. Coons Machine Shop

B. Mon-Dak Stih1

C. Hill City Standard

Grand Total
418.42

431.37

AMOUNT

DATE PAID

June 1975

July 1975

Nov. 1975

Dec. 1975

Aug. 1975

Sept. 1975

Jan. 1976

743.90

Sept. 1975

75.70

Sept.1975

July-Nov. 1975

March 1976

16.00

17.25

9.00

Aug. 1975

Aug. 1975

Sept. 1975 

